\title{
Enzymes immobilized in Langmuir-Blodgett films: Why determining the surface properties in Langmuir monolayer is important?
}

\author{
LUCIANO CASELI
}

Institute of Environmental, Chemical and Pharmaceutical Sciences, Federal University

of São Paulo, Rua São Nicolau, 210, 09913-030 Diadema, SP, Brazil

Manuscript received on June 12, 2017; accepted for publication on July 26, 2017

\begin{abstract}
In this review we discuss about the immobilization of enzymes in Langmuir-Blodgett films in order to determine the catalytic properties of these biomacromolecules when adsorbed on solid supports. Usually, the conformation of enzymes depends on the environmental conditions imposed to them, including the chemical composition of the matrix, and the morphology and thickness of the film. In this review, we show an outline of manuscripts that report the immobilization of enzymes as LB films since the 1980's, and also some examples of how the surface properties of the floating monolayer prepared previously to the transfer to the solid support are important to determine the efficiency of the resulting device.
\end{abstract}

Key words: Langmuir-Blodgett, enzymes, biosensors, air-water interface.

\section{INTRODUCTION}

The detailed preparation of Langmuir-Blodgett films was first introduced by Katharine Blodgett (Blodgett 1934) and involves the vertical passage of a solid support through a floating monolayer at the liquid-gas interface (usually air-water interface). This assembly, commonly named "Langmuir monolayer", or "Langmuir film", was firstly reported by Benjamin Franklin (Franklin et al. 1774), who went on to experiment with oil, spreading monomolecular films on bodies of water, reporting the mutual repulsion between the particles of oil and the lack of attraction

\footnotetext{
E-mail: lcaseli@unifesp.br

* Contribution to the centenary of the Brazilian Academy of Sciences.
}

between oil and water due to the effect of calming water waves. Franklin was the first, therefore, to describe roughly the phenomenon of spreading of hydrophobic compounds due to repulsive forces.

After more than one century, Agnes Pockels described the manipulation of oil films on water at her kitchen bench and sent the results to Lord Rayleigh, who arranged the publication of these results in Nature (Pockels 1891a, b). Pockels measured the first surface tension of lipid monolayers with her device and could calculate the thickness of the film as being around $13 \AA$, suggesting a film with one molecule thickness.

After someyears, Irving Langmuir, who worked in General Electric, invented a trough similar to that of Pockels' apparatus, but with the addition of a barrier permitting the compression of the films. 
With this trough, later called "Langmuir trough", it was possible to obtain the so-called surface pressure-area isotherms, which allowed knowing the cross-section areas of many amphiphilic molecules. Katharine Blodgett, in 1934 (Blodgett 1934), extended Langmuir's work by developing a method to transfer the monomolecular films onto solid supports (or substrates) like glass or metal. For this pioneering work, these films have been then called Langmuir-Blodgett (LB) films.

Since then, many applications from Langmuir and LB films have been pursued, and they include the use of Langmuir monolayers as models for cellular membranes (Brockman 1999, Brezesinski and Möhwald 2003), and LB films for the construction of nanostructured devices. The study of LB films was mostly scientific and fundamental until 1970 (Moriizumi 1988), and then other potential applications has been outlined by some authors (Swalen et al. 1987). These applications include the miniaturization of electronic devices for molecular electronics (Heath 2009) and for chemical and biological sensors (Moriizumi 1988). Moriizumi and collaborators (Sriyudthsak et al. 1988 ) in the 1980's alleged that the main advantages of molecular deposition using the LB method are related to the possibility of forming ultrathin films, being a precise technique for packing and stacking molecules; as well as it is able to fabricate biomimetic membrane materials. As a result, films fabricated with the LB technique has shown a high potential for improving the performance of sensors since they offer a wide selection of material in a close-packed structure. In this review, we outline the recent advancements on the immobilization of enzymes in Langmuir-Blodgett films and how the knowledge about the properties of the previous Langmuir monolayers are important to boost the performance of enzymes immobilized as LB films for sensing. A brief review on proteins and enzymes spread on liquid interfaces is first presented and then the use of enzyme-lipid LB films is outlined and discussed. The basic idea of using this assembly (as Figure 1) is that the amphiphilic structure of the lipids helps not only the attachment of the enzyme to the interface, but also conserves better its conformational properties.

\section{ENZYMES AND OTHER PROTEINS SPREAD ON THE AIR-WATER INTERFACE}

Many proteins are soluble in water, so their spreading on the air-water interface can lead to the partition of molecules between the interface and the aqueous subphase. As they are amphiphilic, the surface excess of proteins lead to the formation of Gibbs monolayers as reported in pioneering works (Gaines 1966). The amount of proteins at the interface can be increased using high salt concentrations at the aqueous subphase (Yano et al. 2011), but care with possible denaturation may be taken into account. Usually, the pre-formation of a stable Langmuir monolayer at the air-water interface (formed, for instance, by lipids) may also help avoid denaturation of proteins adsorbing from the aqueous subphase (Girard-Egrot et al. 2005) since the amphiphilic nature of lipids may help conserve the structure of the polypeptide moiety of the protein. Nowadays, this kind of study is not problematic since modern techniques can be employed in order to analyze the possible effects of proteins adsorbed at the air-water interface.

Particularly, changes in the conformation of enzymes, either at the air-water interface, or transferred to solid supports as LB films, may affect its catalytic efficacy (Girard-Egrot et al. 2005, Siqueira Jr et al. 2010, Iost et al. 2011). However, possible physical chemical properties can be investigated previously to the transfer to solid supports. There has been a debate in the literature about the changes in the structure of the film when it is transferred from the liquid interface to a solid support. Understanding such changes is relatively complex since it involves variables such 


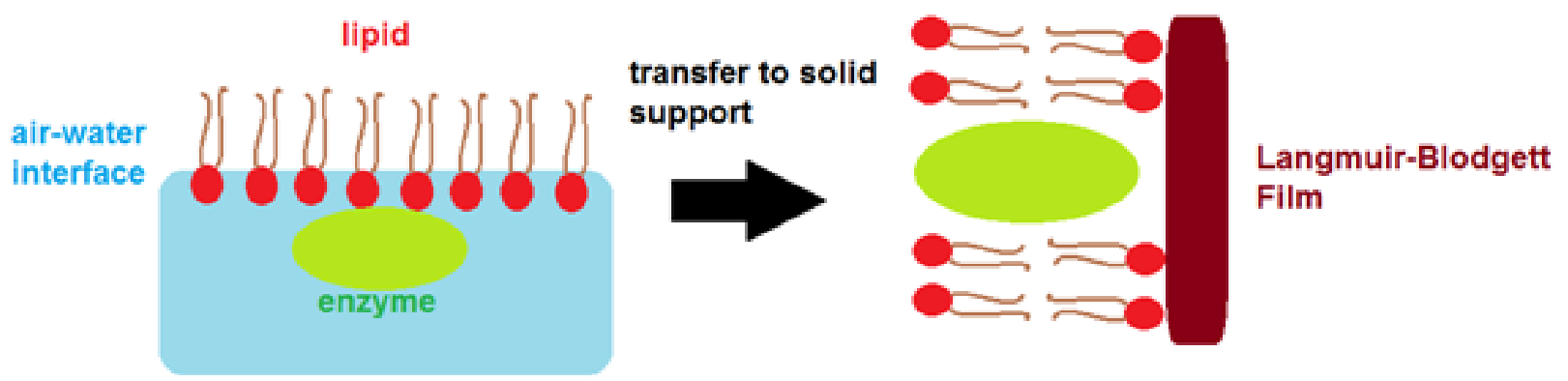

Figure 1 - Scheme for the transfer of mixed lipid-enzyme monolayers to solid support as Langmuir-Blodgett (LB) films.

as the surface pressure of deposition, the chemical composition of the monolayer and of the aqueous subphase, the rheological properties of the film, the nature of the solid support, the number of deposited layers, the architecture of the LB films (monolayer or multilayer of the types X, Y or $Z$ ), and other details related to the way how the film was transferred (dipping rate, time of drying between successive depositions, stability of the floating monolayer during the deposition, etc.).

With these ideas in mind, this review discusses some important points related to these properties, especially those involved in the floating monolayers when enzymes are adsorbed at the air-water interface previously to the transfer to LB films.

\section{BRIEF REVIEW ON ENZYMES ADSORBED AS LB FILMS}

The first reports on enzymes immobilized in LB films are essentially based on urease and glucose oxidase (GOD), with their activity studied for urea and glucose sensing purposes, respectively. In the presence of oxygen, glucose is oxidized and hydrogen peroxide is produced accordingly. $\mathrm{H}_{2} \mathrm{O}_{2}$, is usually monitored by an amperometric electrode taking the advantage of the fact that the current under $0.6 \mathrm{~V}$ bias is proportional to the peroxide concentration (and therefore to glucose concentration). Although this method is not common to follow reaction kinetics, it is very useful for analytic purposes.
Pioneers in immobilizing enzymes as LB films, Miyahara and collaborators (Miyahara et al. 1983, Takatsu and Moriizumi 1987, Onoue et al. 1987) developed a urea sensor and several types of glucose sensors. Later, Sriyudthasak and collaborators (Sriyudthsak et al. 1988) reported a lipid-protein monolayer for a biosensor prepared utilizing the LB technique. GOD was immobilized in the lipid monolayer by adsorption from the subphase, whose interaction was dominated by electrostatic forces. Finally, a glucose sensor was fabricated by depositing the film onto a hydrogen peroxide electrode. Other GOD-lipid LB films were sequentially proposed deposited on a Pt electrode acting as a glucose-sensing with a short response time, and determined amperometrically (Okahata et al. 1988). Later on, other researchers (Anzai et al. 1989), instead of lipids, employed a synthetic polymer (polyethyleneimine) as matrix for enzyme immobilization. This polymer was called "spacer" since it allows for the homogeneous spreading of urease at the air-water interface. The idea was that the enzyme could aggregate at the interface and insoluble amphiphiles with a positive spreading coefficient could help avoid such aggregation. Interestingly, they reported a covalent linking between the enzyme and the polymer, instead of electrostatic interactions.

Later on, Zhu et al. 1989 was the first to prove the presence of the enzyme in the mixed GODlipid LB films by using infrared spectroscopy. The presence of amide bands in the fingerprint spectrum 
releveled not only the successful co-transfer of the enzyme, but also could be interpreted in terms of conformation of the biomacromolecule. The authors immersed the films in water several times and tested the ability of the enzyme to remain adsorbed on the solid support. UV-vis spectroscopy was also employed to determine the adsorption of enzymes (Miyauchi et al. 1989) and to estimate the amount of enzyme adsorbed. Later, the amount of the enzymes urease and GOD adsorbed at lipid monolayers at the air-water interface was measured. A urea sensor, using an ion sensitive field effect transistor (ISFET) as a transducer, was constructed with urease immobilized by the LB technique (Miyauchi et al. 1989, Arisawa and Yamamoto 1992). Since them, other advanced techniques have been employed to better investigate the structure of enzyme-lipid LB films (Berzina et al. 1996). In this case, ellipsometry, infrared spectroscopy and atomic force microscopy were employed to study the thickness, chemical composition and morphology of the deposited films of glutathione-S-transferase. They observed no considerable denaturation of the enzyme in selected conditions since the enzyme activity could be detected in the films. Barraud 1990 prepared LB films as a phosphine sensor which provided a high sensitivity and easy transduction. However, they discuss that the defects in LB films remained a major problem since it governs the response time, which depends strongly on the thickness of the films (the thinner, the faster). Another remarkable example reports octanodecanol and octadecylamine Langmuir monolayers with ferrocene incorporated. The hybrid monolayer was deposited on electrodes and then immersed in a solution with GOD, allowing for a covalent linking with glutaraldehyde (Tatsuma et al. 1991). This method permitted the detection of glucose amperometrically, showing an alternative method of preparation of LB films coupled with covalent linking. Although this method is more restricted for the enzyme to accommodate molecularly, leading to possible effects of denaturation, it must provide a rigid attachment of the enzyme to the solid matrix and therefore more stability.

Nakagawa et al. 1981 showed that it is not strictly necessary to use insoluble amphiphiles at the air-water interface to allow for enzyme adsorption and subsequent LB transfer. They discuss the employment of a subphase with high saline concentration and guaranteed a high amount of GOD or cytochrome $\mathrm{c}$ at the air-water interface (salting out effect). Subsequently, they transferred the enzyme to solid supports by means of the socalled Fromherz method (Fromherz 1971, 1975), by which they utilized a multi-compartment LB trough that allowed for the transfer of the enzyme monolayer to a lateral compartment containing a subphase with pure water. This method allowed the absence of salts in the transferred film, and kept partially the enzyme activity in the LB film. Later, Fiol et al. 1982 employed atomic force microscopy to image, at a molecular level, an LB film consisting of mixed layers of behenic acid and GOD, prepared by the LB technology. This report showed the enzyme molecules organized in parallel ridges, being one of the first papers that tried to correlate the chemical structure of enzyme-lipid films with their surface morphology.

Berzina et al. 1996 reported a strategy to avoid protein denaturation during deposition, in which adsorption of the protein layer was carried out from an aqueous solution onto a hydrophilic surface of a previous deposited monolayer. A protective monolayer of another surfactant is then deposited over the adsorbed protein molecules. In this process, proteins avoid contact with the air-water interface and then the films were construct with the structure of monolayer of surfactant I /adsorbed protein layer/monolayer of surfactant 2 . The main reason for the loss of the functional properties of proteins is the contact with air. When this is avoided, native proteins are preserved in the films, as demonstrated by the high activity of the enzyme layers. A correct 
choice of monolayer for enzyme adsorption and protection enables a value of the specific activity comparable with that for dissolved molecules. Later, Zaitsev 1993 showed that optimization of the enzymatic properties of GOD can be done by choosing the correct lipid that forms the monolayer at a specific $\mathrm{pH}$. This paper defended that since enzymes are electrically charged depending on the $\mathrm{pH}$, electrostatic interactions between negative or positive lipids can influence the conformation of the enzyme.

Although these first papers were focused on enzymes like GOD and urease, other enzymes started to be investigated using lipid-enzyme mixed films. For instance, choline oxidase activity was retained in Langmuir-Blodgett (LB) films prepared with behenic acid or with mixed dipalmitoylphosphatidylcholine (DPPC) and dipalmitoylphosphatidic acid (DPPA) (Iost et al. 2011, Rao et al. 1997, Girard-Egrot et al. 1998). The enzyme activity could be detected by means of an electrochemical sensor whose platinum electrode was coated with the protein-lipid LB films. The hydrophilic environment provided inactivated choline oxidase due to a competition with choline moiety of DPPC. On the other hand, the environment provided by fatty acid multilayers retained better the activity of the enzyme. Pal et al. 1994 produced a voltammetric ethanol sensor by producing alcohol dehydrogenase stearic acid LB film. Interestingly, Antolini et al. 1996 constructed a Glutathione-S-transferase LB films to detect triazinic pesticides. The enzyme formed a Gibbs monolayer on pure water and was directly transferred to solid supports as LB films. By characterizing the films by means of circular dichroism spectroscopy, nanogravimmetry, and spectrophotometry, they determined the structure, surface density, and functional activity of the enzyme when packed in the monolayers. The properties of the LB films were also conducted as a function of the number of layers and of the temperature, and the enzyme activity was determined optically. While the kinetic response as a function of layers suggested that only the external layer was active, the film activity as a function of temperature indicated that the enzyme in this LB film appears to strictly preserve its functional activity and thus its structure up to $423 \mathrm{~K}$, which is highly encouraging for a biosensor application, considering that both structure and function were preserved after the deposition. Although the Gibbs monolayer of the enzyme may contain denatured proteins, this denatured layer would decrease the water surface tension, protecting the lowest protein layers from denaturation. When this enzyme was deposited in hydrophobic surfaces (Paddeu et al. 1995), the enzyme showed higher activity, which was kept after 5 months onto the activated substrate and only a small decrease in activity was observed. The films were also terminally more stable than enzymes in solution. Marron-Brignone 1996 obtained similar results with luciferase. The results reported that a weak amount of enzyme is specifically linked to the surface and does not depend on the subphase concentration. Also, it did not desorb towards the buffer during the detection of its activity. However, its kinetic behavior is different from that of the free enzyme. Immobilization on lipidic surfaces prevented the inhibition due to the production of oxyluciferin during catalysis and created a favorable microenvironment so that the activity was improved.

More recently, Girard-Egrot et al. 1997 showed that the activity of enzyme glutamate dehydrogenase immobilized in behenic acid LB films depends on the changes in the structure of the lipid due to aging and contact with ionic solutions. Another example remarkable to be mentioned is the use of submicron hydrophobic $\mathrm{SiO}_{2}$ particles as Langmuir-Blodgett (LB) films that helped incorporate GOD (Tang et al. 1992). The results showed not only the maintenance of the enzymatic activity, but the increase of the lifetime of the GOD- 
LB film containing $\mathrm{SiO}_{2}$ particles, which is much longer than the lifetime of GOD-LB film without $\mathrm{SiO}_{2}$ particles.

Another approach recently employed was the construction of an amperometric lactose biosensor by co-adsorbing lactase and galactose oxidase in Langmuir-Blodgett (LB) films of poly(3-hexyl thiophene) (P3HT)/stearic acid for dosage of lactose in milk and its derivatives in specific products for people owing "lactose intolerance" (Sharma et al. 2004). The working electrode could be used for the estimation of lactose/galactose in food and also in biological fluids.

Recently, other more complex architectures have been developed to improve the performance of LB-based enzyme sensors. For example, Sun et al. 2010 employed pyriduylthio-modified carbon nanotubes as Langmuir-Blodgett films to support hydrogenase added in a subsequent adsorption from solution for applications in biohydrogen evolution and $\mathrm{H}_{2}$ biofuel cells. Also a uric acid biosensor fabricated by using the LB technique to immobilize the uricase on chitosan/Prussian blue (CS/PB) prefunctionalized indium-tin oxide (ITO) electrode (Wang et al. 2010).

Also, Godoy et al. 2005 constructed a highly organized proteo-lipidic nanostructure which was designed using interfacial liposome fusion and Langmuir-Blodgett techniques. By inserting a non-inhibitor monoclonal antibody in a functional position, this nanostructure was able to sequester acetylcholinesterase (AChE) in a suitable orientation and to maintain the enzyme activity for several months. This molecular assembly has been intimately associated with a performant optical screen-printed choline sensor based on luminol electrochemiluminescence. The linear range for acetylcholine extends over more than two decades, with satisfactory detection limit.

Other complex architectures involve carbon nanotubes (Caseli and Siqueira 2012), polysaccharides (de Brito et al. 2015, Rocha et al. 2016) and synthetic polymers (Barbosa et al. 2016). In all these studies, it is reported that that the enzyme activity determination is crucial, especially for optical sensors, where the optical signal derives directly from the catalytic reaction of the enzyme. Although the enzyme activity tends to be lower in relation to the homogeneous environment (GirardEgrot et al. 2005) because of the restriction of the enzyme in terms of translational movements, the better preservation of the enzyme activity for weeks is reported for several enzymes, including saccharose phospholylase (Rocha et al. 2016), penicillinase (Scholl and Caseli 2015), lactase (Ayoub and Caseli 2017) and rhodanese (de Araujo and Caseli 2016). However, for some cases, the enzyme activity could be even higher than that calculated for the homogeneous environment, which is the case where the catalytic site is a heme group instead of a polypeptide moiety of the enzyme (Schmidt et al. 2008, Goto et al. 2010). Other examples involve also the use of enzyme based LB films for sensor purposes as an electronic tongue (Pavinatto et al. 2011).

Also interesting is the fact that the architecture of the films can be changed by varying the number of layers, and the manner how the enzyme is incorporated in the lipid LB films (from the subphase or from a separated solution in contact with a pre-formed lipid LB film). Apetrei et al. 2012 showed that such parameters affect considerably the enzymatic properties of the bionanodevice. Clop et al. 2008 showed how the molecular packing of lipid monolayers tunes the activity of a galactosidase incorporated $\mathrm{n}$ LB films.

Other interesting works in the literature that involve LB films of enzymes that can be cited are (i) butyrylcholinesterase LB films to construct an enzymatic field effect transistor for the detection of organophosphorus pesticides in water (Wan et al. 2000); (ii) a fiber-optic biosensor consisting of an acetylcholinesterase immobilized LangmuirBlodgett (LB) film to detect organophosphorus 
compounds in contaminated water (Choi et al. 2001); and (ii) a 'protective plate' method to include protein layers into a LB assembly without contact of protein molecules with the air-water interface thus avoiding their denaturation. This strategy was applied for the deposition of biocatalysts with active layers of penicillin G acylase (PGA) (Pastorino et al. 2002) which preserved an enzyme widely used for medicine production. Also, we can cite: (iv) galactose oxidase Langmuir-Blodgett (LB) films of poly(3-hexyl thiophene) (P3HT)/stearic acid (SA) for the estimation of lactose in milk and its products to prevent "lactose intolerance" (Zheng et al. 2004) where the stability was observed for 120 days; (v) laccase and tyrosinase mixed with octadecyltrimethylammonium bromide and with linoleic acid to detect cathecol (Cabaj et al. 2010); (vi) cholesterol oxidase immobilized in LB films consisting of positively charged octadecyltrimethylammonium and nano-sized Prussian-blue clusters (Ohnuki et al. 2009); (vii) a uricase- chitosan -n-nonadecanoic acid LB films to detect uric acid (Wang et al. 2010); (viii) Hyaluronidase-phospholipid LB films designed to determine hyaluronic acid by using fluorescence spectroscopy (Monteiro et al. 2011); (ix) tyrosinase incorporated in a lipidic layer and the use of lutetium bisphthalocyanine as an electron mediator for the voltammetric detection of phenol derivatives, which include one monophenol (vanillic acid), two diphenols (catechol and caffeic acid) and two triphenols (gallic acid and pyrogallol) (Apetrei et al. 2012) (x) a bioelectronic tongue based on lipidic nanostructured layers containing phenol oxidases for the analysis of grapes by means of amperometric and capacitance measurements (Pavinatto et al. 2011); and (xi) malate dehydrogenase-cationic lipid systems to determine malic acid (Gur et al. 2016).

Table I summarizes some highlights on the development of bionsensors based on LB films reported in the last three decades.

\section{PROPERTIES OF THE FLOATING FILMS INFLUENCING THE CATALYTIC PROPERTIES}

Langmuir monolayers that prepared prior to the transfer to solid support influence the properties of LB films. An example was carried out in a set of papers reported on the immobilization of an alkaline phosphatase as mixed lipid LB films, where it was determined the enzyme activity of alkaline phosphatase in LB films, resulting in a film with a significant loss of the enzyme activity (Caseli et al. 2004, 2005b). The enzyme activity was dependent on the lipidic anchor linked to the enzyme since it is a GPI enzyme. The orientation of the main axis of the ellipsoid enzyme in relation to the lipidic matrix surface is not only dependent on the presence of the GPI anchor, but also determines the best exposure of the catalytic site to the solution where the catalytic substrate were present (see scheme in Figure 2). This film could be studied by a variety of techniques involving atomic force microscopy (Caseli et al. 2007), IRRAS (Caseli et al. 2008a). However a previous study on the conformation of the enzyme at the previous Langmuir monolayer was important in order to access information on the physicochemical properties of the floating monolayer (Caseli et al. 2005a). For the enzyme alkaline phosphatase, the enzyme activity could be determined directly at the Langmuir monolayer. First, it was guaranteed that the enzyme was only present at the interface and not in the aqueous subphase. The catalytic substrate was inserted (Figure 3) at the air-water interface and the enzyme activity was measured controlling the formation of p-nitrophenolate at $410 \mathrm{~nm}$ (Caseli et al. 2005b). This procedure was carried out at different levels of packing. As expected, the enzyme activity increased as long as the surface pressure increased since a higher number of enzyme molecules per area is present when the film is compressed. However, after the monolayer passed by a transition from the liquid-expanded phase to a liquid-condensed phase 
TABLE I

Examples of enzymes incorporated in LB films.

\begin{tabular}{|c|c|c|c|}
\hline Enzyme & Architecture & Main finding & Ref. \\
\hline GOD & Enzyme + Arachidic Acid & Electrochemical detection of glucose & Miyahara et al. 1983 \\
\hline Urease & Enzyme + Stearylamine & Colorimetric detection of urea & Miyauchi et al. 1989 \\
\hline $\begin{array}{l}\text { Alcohol Dehydrogenase } \\
\text { and Cellulase }\end{array}$ & Enzymes + DPPC & Identification of products with infrared & Rodrigues et al. 2014 \\
\hline Hyaluronidase & Enzyme + DPPC & $\begin{array}{l}\text { Catalytic Activity of Hyaluronic acid } \\
\text { with fluorescence }\end{array}$ & Monteiro et al. 2011 \\
\hline Urease & $\begin{array}{c}\text { Urease }+ \text { Carbon Nanotube } \\
+ \text { DMPA }\end{array}$ & $\begin{array}{l}\text { Increase of enzyme activity } \\
\text { (colorimetry) }\end{array}$ & Caseli and Siqueira 2012 \\
\hline Tyrosinase & $\begin{array}{l}\text { Enzyme }+ \text { Arachidic Acid }+ \\
\text { Lutetium bisphthalocyanine }\end{array}$ & Voltammetric sensor for pyrogallol & Pavinatto et al. 2011 \\
\hline
\end{tabular}

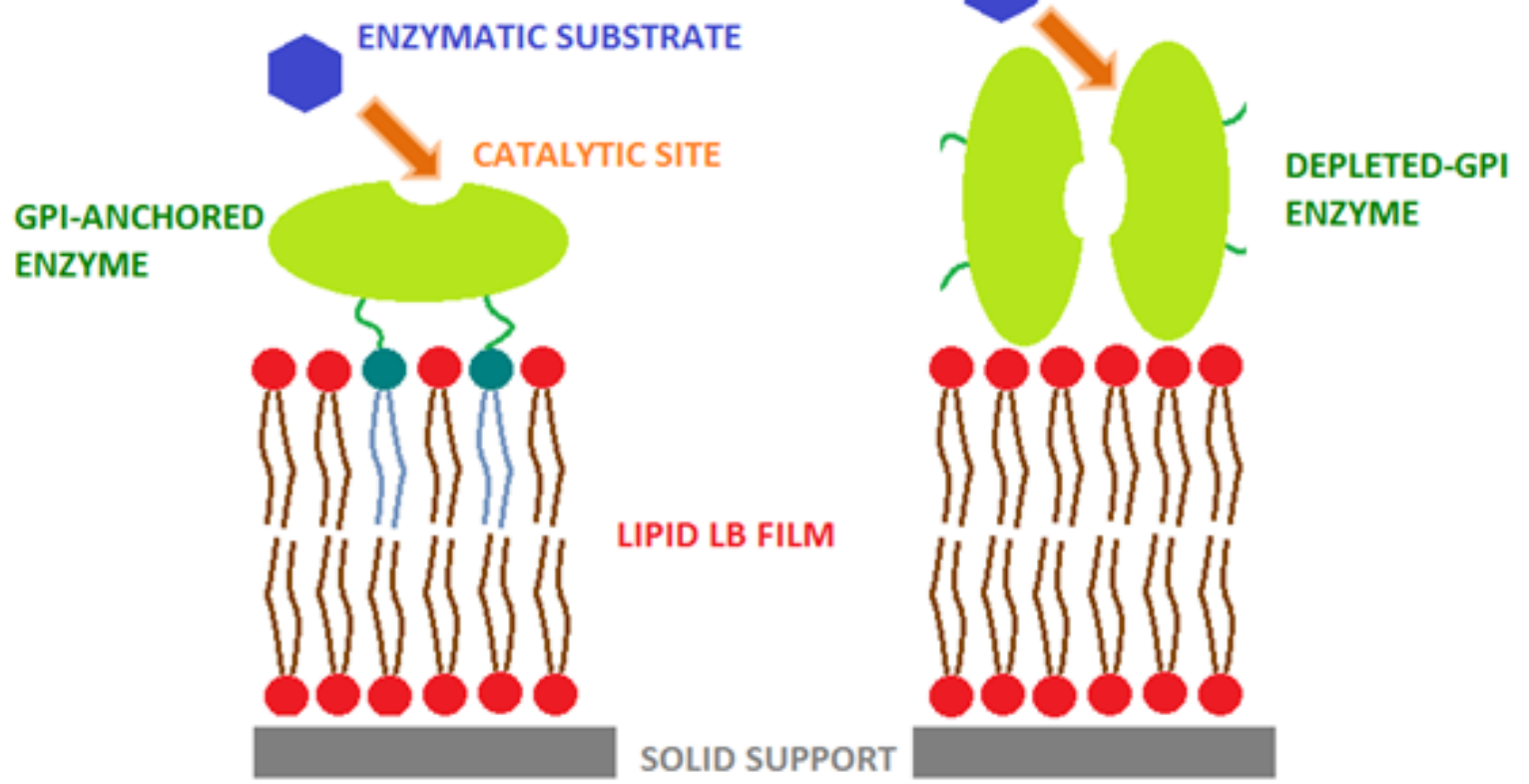

Figure 2 - Scheme for the immobilization of alkaline phosphatase on DMPA LB films and their effect on the access of the substrate to the catalytic site. At left the enzyme contains the GPI anchor intact, and at right the GPI anchor is depleted.

one (second-order transition), the enzyme activity decreased. As a result, a direct relation between the surface compressional modulus and the enzyme activity could be observed. Also, fluorescence microscopy (Caseli et al. 2005b) showed that a different pattern of morphology is noted during this transition, showing how the state of aggregation of the enzyme at the interface is affect by the change in the rheological properties of the film.

General speaking, the viscoelastic properties of a floating monolayer is more important than the surface pressure or the surface density itself. For a Langmuir film the surface elasticity (E) at a given temperature $(\mathrm{T})$ could be calculated based on this following equation by Davies and Riedel (Davies and Riedel 1963);

$$
\mathrm{E}=-1 / \mathrm{A}()_{\mathrm{T}}
$$

This means that the stress provoked by the barrier (or decrease of the area, A) will provide an increase of the surface pressure $(\pi)$. The magnitude of the increase by area decrease, parameterized by 


\section{hydrophobic anchors}

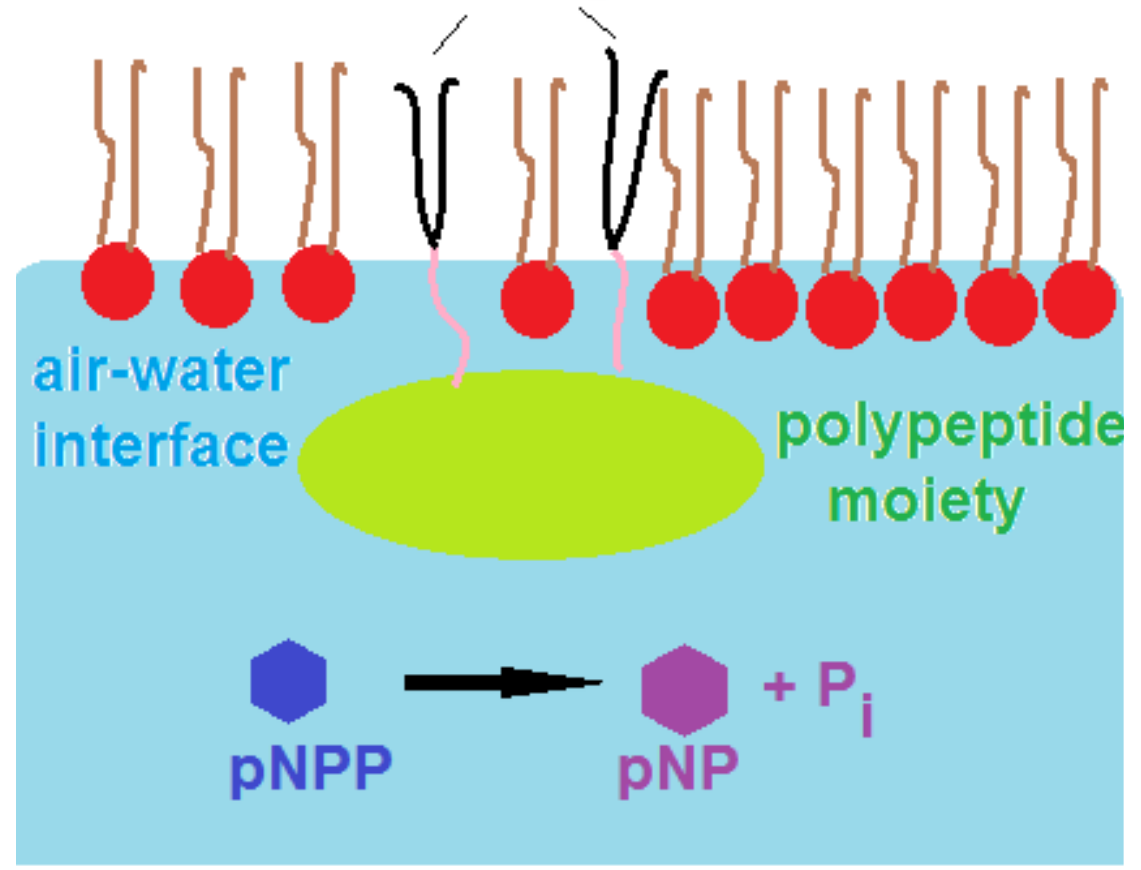

Figure 3 - Scheme for the experiment shown in (Caseli et al. 2005b) where a GPIanchored enzyme (alkaline phosphatase) forms a lipid-enzyme Langmuir monolayer mimicking the out layer of a plasmatic membrane. pNPP (p-nitrophenhophosphate) is inserted in the aqueous subphase and the reaction producing $\mathrm{p}$-nitrophenolate $(\mathrm{pNP})$ and inorganic phosphate $\left(\mathrm{P}_{\mathrm{i}}\right)$ can be monitored in situ using UV-vis spectroscopy.

a given value of area, is the value E, also known as compressional modulus. This quantity is the reciprocal of the compressibility of the films, and it indicate that the more compressible the film, the less elastic it is. Usually at higher stages of compression, the monolayer attains more condensed phases, like the liquid-condensed and the solid states. This leads to an abrupt increase of the surface pressure with compression, and, for this reason, high values of elasticity is usually associated to the rigidity of the monolayer. Usually fatty acids or phospholipid with saturated alkyl chains give monolayers that can reach high values of surface elasticity because of their ability to close pack. Cholesterol is also a classical example of monolayer that reaches higher values of elasticity. These values also vary from 0 to $600 \mathrm{mN} / \mathrm{m}$, and the interval of $100-200 \mathrm{mN} / \mathrm{m}$ is considered the transition between expanded and condensed states. Usually the existence of chains with gauche deformations, usually associated to unsaturations in the alkyl chain, and even the introduction of a flexible second component like a protein, leads to a more flexible monolayer, which gives the film more flexibility to rearrange molecularly when compressed. This leads to a lower rate of pressure increase and a consequent decrease in the values of surface elasticity.

Usually enzymes adsorbed in rigid Langmuir monolayer tends to make the film more flexible, smoothing the response of the interface to the compression. Also, during the compression, molecular changes in the protein conformation in terms of orientations and secondary structure can be observed, leading the enzyme to more relaxed 
or tenser states. This could lead to phenomena such as aggregation and desorption of the enzyme towards the aqueous subphase. Process related to desorption/adsorption of materials to/from interface, as well as the shear between lateral layers provided by the process of molecular accommodation can originate viscous properties of the film. This could be usually measured using dynamic techniques such as determination of the inclination of surface pressure-area isotherms, which give quasi-equilibrium properties, or oscillating barriers and pulsating pendent drop, which give dynamic parameters. Particularly, for films containing alkaline phosphatase, a complete study using pendent drop could be carried out, where it was observed that the viscous contribution may play an important role in the surface and catalytic properties of this enzyme. Also, for other enzymes, dynamic rheological properties could be determined (Caseli et al. 2006) and correlated with how a decrease in the surface elasticity affects the properties of enzyme-lipid films. The rheological properties of the air-water interface can be also determined by using a small floating road that moves due to the action to a magnet field (Rossini et al. 2017). Usually the values of elasticity obtained are lower, but give information that can be correlated to viscous and purely elastic properties of Langmuir monolayers.

The morphology of Langmuir films is also an important aspect to be evaluated. For instance, urease mixed with synthetic polymer monolayers (Barbosa et al. 2016) is reported to be highly heterogeneous at the air-water interface, and this pattern of morphology is maintained for the LB films as observed with atomic force microscopy. IRRAS has also been an usefully technique to evaluate enzymes adsorbed at lipid monolayers since the position of amide I and II bands is related to the secondary conformation of the polypeptide moiety in term of $\alpha$-helices or $\beta$-sheets. Ronzon et al. reported an extensive study on the conformation of an alkaline phosphatase adsorbed at the air-water in different situations (Ronzon et al. 2002), in the same way did by Caseli et al. 2008a for a homologous alkaline phosphatase. Since then IRRAS has been employed to confront the morphology of enzyme before and after the deposition (Rodrigues et al. 2014) in order to check possible molecular rearrangements during the deposition and how this affect the enzyme stability. Although some changes are reported (Rodrigues et al. 2014, Zanon et al. 2012), the enzyme-LB film maintains part of the catalytic properties and the molecular environment helps conserve the enzyme activity better than the enzyme in homogeneous environment (dissolved in aqueous solution).

Urease, although reported in the first reports, was reported recently that able to be transferred from pure Gibbs monolayers (Hou et al. 2002), and have its catalytic properties enhanced with mixed at the air-water interface with anionic lipids (Caseli et al. 2008b), carbon nanotubes (Caseli and Siqueira 2012), synthetic polymers (Barbosa et al. 2016) or algal polysaccharides (de Brito et al. 2015).

Other example interesting to be mentioned was carried out by Dziri et al. 1997. The surface topography of the enzyme acetylcholinesterase was studied at the air/aqueous and the air/solid interfaces using Brewster angle (BAM) and the atomic force microscopies, respectively. Surface potential of the enzyme monolayer was measured in conjunction with the surface pressure and BAM, suggesting the presence of domains in the film, with the size of these domains increasing when the molecular area decreases. Furthermore, the Brewster angle microscopy allowed them to detect a reversible formation of the domains upon compression and decompression of the monolayer. On the other hand, the atomic force microscope images of the LB films showed that the enzyme molecules are more close-packed at high values of surface pressure. Size measurements of the enzyme particles indicate that acetylcholinesterase has 
an ellipsoidal shape and that the tetrameric form of this enzyme is the most abundant. This was, therefore, an interesting study on the correlation of thermodynamic, structural and morphological properties of Gibbs monolayers of enzymes and their deposition to solid supports as LB films. Finally, organophosphorus hydrolase could be investigated in both at the air-water interface and on LB films by using circular dichroism and epifluorescence where the dependence of the structure on the temperature could be evaluated (Zheng et al. 2004). These studies allowed for the better detection of paraoxon.

\section{CONCLUSION}

A wide range of possible applications for enzymes confined as LB films is encountered in the literature. Although there are many competing technologies for the production of ultrathin films, for commercial exploitation, it is important to establish which areas LB films offer significant advantages over films produced by other means. Bioinspired and nano-organized membranes based on LB technology present a real interest for applied nano-biosciences and nano-materials. A number of molecular assemblies produced with enzymes confined in LB films mixed with other compounds, biological or synthetic have been demonstrated to be adapted for biocatalysis investigations of immobilized enzymes in a favorable environment. This fact, associated with the performance of devices able to recognize the reaction and promote physical signals for transducing, is promising for the developments of sensors organized at the molecular level and detailed investigation of biological processes is fundamental. As a matter of fact, an accurate knowledge on the conformation of biomolecules confined in ultrathin films, as well as the development of different kinds of molecular assemblies, allow for fundamental and applied investigations of enzymes immobilized in miniaturized devices.

\section{ACKNOWLEDGMENTS}

The author thanks Fundação de Amparo à Pesquisa do Estado de São Paulo (FAPESP; 2015/10851-0), Coordenação de Aperfeiçoamento de Pessoal de Nível Superior (CAPES), and Conselho Nacional de Desenvolvimento Científico e Tecnológico (CNPq).

\section{REFERENCES}

ANTOLINI F, PADDEU S AND NICOLINI C. 1996. Heat Stable Langmuir-Blodgett Film of Glutathione-STransferase. Langmuir 11: 2719-2725.

ANZAI J, LEE S AND OSA T. 1989. Enzyme-immobilized Langmuir-Blodgett membranes for biosensor application. Use of highly branched polyethyleneimine as a spacer for immobilizing a-chymotrypsin and urease. Makromol Chem Rapid Commun 10: 167-170.

APETREI C, ALESSIO P, CONSTANTINO CJL, DE SAJA JA, RODRIGUEZ-MENDEZ ML, PAVINATTO FJ, FERNANDES EGR, ZUCOLOTTO V AND OLIVEIRA JR ON. 2012. Biomimetic biosensor based on lipidic layers containing tyrosinase and lutetium bisphthalocyanine for the detection of antioxidants Biomimetic biosensor based on lipidic layers containing tyrosinase and lutetium bisphthalocyanine for the detection of antioxidants. Biosen Bioelectron 26: 2513-2519.

ARISAWA S AND YAMAMOTO R. 1992. Quantitiative characterization of enzymes adsorbed on to LangmuirBlodgett films and the application to a urea sensor. Thin Solid Films 210/211: 443-445.

AYOUB FP AND CASELI L. 2017. Controlling the molecular architecture of lactase immobilized in Langmuir-Blodgett films of phospholipids to modulate the enzyme activity. Colloid Surf B 150: 8-14.

BARBOSA CG, CASELI L AND PÉRES LO. 2016. Conjugated polymers nanostructured as smart interfaces for controlling the catalytic properties of enzymes. J Coll Interf Sci 476: 206-213.

BARRAUD A. 1990. Chemical sensors based on LB films. Vacuum 41: 1624-1628.

BERZINA TS, TROITSKY VI, PETRIGLIANO A, ALLIATA D, TRONIN AY AND NICOLINI C. 1996. LangmuirBlodgett films composed of monolayers of amphiphilic molecules and adsorbed soluble proteins. Thin Solid Films 284/285: 757-761. 
BLODGETT K. 1934. Monomolecular films of fatty acids on glass. J Am Chem Soc 56: 495.

BREZESINSKI G AND MÖHWALD H. 2003. Langmuir monolayers to study interactions at model membrane surfaces. Adv Colloid Interf Sci 100-102: 563-584.

BROCKMAN H. 1999. Lipid monolayers: why use half a membrane to characterize protein-membrane interactions. Current Opp Struct Biol 9: 438-443.

CABAJ J, SOŁODUCHO J AND NOWAKOWSKA-OLEKSY A. 2010. Langmuir-Blodgett film based biosensor for estimation of phenol derivatives. Sens Actuators B 143: 508-515.

CASELI L, CRESPILHO FN, NOBRE TM, ZANIQUELLI MED, ZUCOLOTTO V AND OLIVEIRA JR ON. 2008b. Using phospholipid Langmuir and Langmuir-Blodgett films as matrix for urease immobilization. J Colloid Interf Sci 319: 100-108.

CASELI L, FURRIEL RPM, ANDRADE JF, LEONE FA AND ZANIQUELLI MED. 2004. Surface density as a significant parameter for the enzymatic activity of two forms of alkaline phosphatase immobilized on phospholipid Langmuir-Blodgett films. J Colloid Interf Sci 275: 123-130.

CASELI L, MASUI DC, FURRIEL RPM, LEONE FA AND ZANIQUELLI MED. 2005a. Incorporation conditions guiding the aggregation of a glycosylphosphatidyl inositol (GPI)-anchored protein in Langmuir monolayers. Coll Surf B 46: 248-254.

CASELI L, MASSUI DC, FURRIEL RPM, LEONE FA AND ZANIQUELLI MED. 2007. Influence of the glycosylphosphatidylinositol anchor in the morphology and roughness of Langmuir-Blodgett films of phospholipids containing alkaline phosphatases. Thin Solid Films 515: 4801-4807.

CASELI L, MASSUI DC, FURRIEL RPM, LEONE FA, ZANIQUELLI MED, ORBULESCU J AND LEBLANC RM. 2008a. Rat osseous plate alkaline phosphatase as Langmuir monolayer-An infrared study at the air-water interface. J Colloid Interf Sci 320: 476-482.

CASELI L, MORAES ML, ZUCOLOTTO, FERREIRA M, NOBRE TM, ZANIQUELLI MED, RODRIGUES FILHO UP AND OLIVEIRA JR ON. 2006. Fabrication of Phytic Acid Sensor Based on Mixed Phytase-Lipid LangmuirBlodgett Films. Langmuir 2006: 8501-8508.

CASELI L, OLIVEIRA RG, MASSUI DC, FURRIEL RPM, LEONE FA, MAGGIO B AND ZANIQUELLI MED. 2005b. Effect of Molecular Surface Packing on the Enzymatic Activity Modulation of an Anchored Protein on Phospholipid Langmuir Monolayers. Langmuir 2005: 4090-4095.

CASELI L AND SIQUEIRA JR JR. 2012. High Enzymatic Activity Preservation with Carbon Nanotubes.
Incorporated in Urease-Lipid Hybrid Langmuir-Blodgett Films. Langmuir 28: 5398-5403.

CHOI J, KIM Y, LEE I, MIN J AND LEE WH. 2001. Optical organophosphorus biosensor consisting of acetylcholinesterase/viologen hetero Langmuir-Blodgett films. Biosens Bioelectron 16: 937-943.

CLOP EM, CLOP PD, SANCHEZ JM AND PERILLO MA. 2008. Molecular packing tunes the activity of Kluyveromyces lactis beta-galactosidase incorporated in Langmuir-Blodgett films. Langmuir 24: 10950-10960.

DAVIES JT AND RIEDEL EK. 1963. Interfacial Phenomena, Academic Press, New York, United States.

DE ARAUJO FT AND CASELI L. 2016. Rhodanese incorporated in Langmuir and Langmuir-Blodgett films of dimyristoylphosphatidic acid: Physical chemical properties and improvement of the enzyme activity. Coll Surf B 141: 59-64.

DE BRITO AK, NORDI CSF AND CASELI L. 2015. Algal polysaccharides as matrices for the immobilization of urease in lipid ultrathin films studied with tensiometry and vibrational spectroscopy: Physical-chemical properties and implications in the enzyme activity. Coll Surf B 135: 639-645.

DZIRI L, BOUSSAAD S, WANG S AND LEBLANC RM. 1997. Surface Topography of Acetylcholinesterase in Langmuir and Langmuir-Blodgett Films. J Phys Chem B 101: 6741-6748.

FIOL C, ALEXANDRE S, DELPIRE N, VALLETON JM AND PARIS E. 1992. Molecular resolution images of enzyme-containing Langmuir - Blodgett films. Thin Solid Films 215: 88-93.

FRANKLIN B, BROWNRIGG W AND FARISH M. 1774. Of the stilling of waves by means of oil. Phylos Trans R Soc Lond B 64(1774): 445-460.

FROMHERZ P. 1971. New technique for investigating lipid protein films. Biochim Biophys Acta 225: 382-387.

FROMHERZ P. 1975. Instrumentation for handling monomolecular films at an air-water-interface. Rev Sci lnstrum 46: 1380-1384.

GAINES GL. 1966. Insoluble monolayers at liquid-gas interface. Interscience Publishers, New York, A thorough and comprehensive review of the literature on floating monolayers with a short section on LB films.

GIRARD-EGROT AP, GODOY S AND BLUM LJ. 2005. Enzyme association with lipidic Langmuir-Blodgett films: interests and applications in nanobioscience. Adv Colloid Interf Sci 116: 205-225.

GIRARD-EGROT AP, MORÉLIS RM AND COULET PR. 1997. Bioactive nanostructure with glutamate dehydrogenase associated with LB films: protecting role of the enzyme molecules on the structural lipidicorganization. Thin Solid Films 292: 282-289. 
GIRARD-EGROT AP, MORÉLIS RM AND COULET PR. 1998. Direct Bioelectrochemical monitoring of choline oxidase kinetic behaviour in Langmuir-Blodgett nanostructures. Bioelectrochem Bioenerg 46: 39-44.

GODOY S, LECA-BOUVIERA B, BOULLANGER P, BLUMA LJ AND GIRARD-EGROT AP. 2005. Electrochemiluminescent detection of acetylcholine using acetylcholinesterase immobilized in a biomimetic Langmuir-Blodgett nanostructure. Sens Act B 107: 82-87.

GOTO TE, LOPEZ RF, OLIVEIRA JR ON AND CASELI L. 2010. Enzyme Activity of Catalase Immobilized in Langmuir-Blodgett Films of Phospholipids. Langmuir 2010: 11135-11139.

GUR B, ISIK M, KIRANS KS, ALANYALIOGLU M, BEYDEMIR S AND MERAL K. 2016. High enzymatic activity preservation of malate dehydrogenase immobilized in a Langmuir- Blodgett film and its electrochemical biosensor application for malic acid detection. RSC Adv 6: 79792-79797.

HEATH JR. 2009. Molecular Electronics. Ann Rev Mat Res 39: 1-23.

HOU Y, JAFFREZIC-RENAULT N, ZHANG A, WAN J, ERRACHID A AND CHOVELON JM. 2002. Study of pure urease Langmuir-Blodgett films and applications for biosensor development. Sens Act B 86: 143-149.

IOST RM, MADURRO JM, BRITO-MADURRO AG, NANTES IL, CASELI L AND CRESPILHO FN. 2011. Strategies of Nano-Manipulation for Application in Electrochemical Biosensors. Int J Electrochem Sci 6: 2965-2997.

MARRON-BRIGNONE L, MORKLIS RM, BLUM LJ AND COULET PR. 1996. Behaviour of firefly luciferase associated with Langmuir-Blodgett films. Thin Solid Films 284/285: 784-788.

MIYAHARAY, MORIIZUMI T, SHIOKAWA S, MATSUOKA H, KARUBE I AND SUZUKI S. 1983. Micro urea sensor using semiconductor and enzyme immobilizing technologies. J Chem Soc Jpn 6: 823-830.

MIYAUCHI S, ARISAWA S, ARISE T AND RYOICHI YAMAMOTO R. 1989. Study on the concentration of an enzyme immobilized by Langmuir-Blodgett films. Thin Solid Films 180: 293-298.

MONTEIRO DS, NOBRE TM AND ZANIQUELLI MED. 2011. Hyaluronidase Behavior at the Air/Liquid and Air/ Lipid Interfaces and Improved Enzymatic Activity by Its Immobilization in a Biomembrane Model. J Phys Chem B 115: 4801-4809.

MORIIZUMI T. 1988. Langmuir-Blodgett films as chemical sensors. Thin Solid Films 160: 413-429.

NAKAGAWA T, KAKIMOTO M, MIWA T AND IZAWA M. 1991. New method for fabricating langmuir-blodgett films of water-soluble proteins with retained enzyme activity. Thin Solid Films 202: 151-156.
OHNUKI JH, HONJO R, ENDO H AND IMAKUBO T. 2009. Mitsuru Izumi Amperometric cholesterol biosensors based on hybrid organic-inorganic Langmuir-Blodgett films. Thin Solid Films 518: 596-599.

OKAHATA Y, TSURUTA T, IJIRO K AND ARIGA K. 1988. Langmuir-Blodgett films of an enzyme-lipid complex for sensor membrane. Langmuir 4: 1373-1375.

ONOUE Y, MORIIZUMI T, OKAHATA Y AND ARIGA K. 1987. High-quality lb films of artificial dialkyl lipid. Jap J Appl Phys 26: L1897-L1899.

PADDEU S, ANTOLINI F, DUBROVSKY T AND NICOLINI C. 1995. Langmuir-Blodgett film of glutathione S-transferase silanized surfaces. Thin Solid Films 268: 108-113.

PAL P, NANDI D AND MISRA TN. 1994. Immobilization of alcohol dehydrogenase enzyme in a Langmuir-Blodgett film of stearic acid: its application as an ethanol sensor. Thin Solid Films 239: 138-143.

PASTORINO L, BERZINA TS, TROITSKY VI, FONTANA MP, BERNASCONI E AND NICOLINI C. 2002. Biocatalytic Langmuir-Blodgett assemblies based on penicillin G acylase. Coll Surf B 23: 357-363.

PAVINATTO FJ, FERNANDES EGR, ALESSIO P, CONSTANTINO CJL, DE SAJA JA, ZUCOLOTTO V, APETREI C, OLIVEIRA JR ON AND RODRIGUEZMENDEZ ML. 2011. Optimized architecture for Tyrosinase-containing Langmuir-Blodgett films to detect pyrogallol. J Mat Chem 21: 4995-5003.

POCKELS A. 1891a. Surface Tension. Nature 43: 437-439.

POCKELS A. 1891b. On the relative contamination of the water-surface by equal quantities of different substances. Nature 46: 418-419.

RAO NM, PLANT AL, SILIN V, WIGHT S AND HUILL SW. 1997. Characterization of Biomimetic Surfaces Formed from Cell Membranes. Biophys J 73: 3066-3077.

ROCHA RM, PAVINATTO A, NOBRE TM AND CASELI L. 2016. Carrageenan Changes the Physicochemical Properties of Mixed Enzyme-Lipid Ultrathin Films and Enhances the Catalytic Properties of Sucrose Phosphorylase Nanostructured as Smart Surfaces. J Phys Chem B 120: 5359-5366.

RODRIGUES D, CAMILO FF AND CASELI L. 2014. Cellulase and Alcohol Dehydrogenase Immobilized in Langmuir and Langmuir-Blodgett Films and Their Molecular-Level Effects upon Contact with Cellulose and Ethanol. Langmuir 30: 1855-1863.

RONZON F, DESBAT B, CHAUVET JPAND ROUX B. 2002. Penetration of a GPI-anchored protein into phospholipid monolayers spread at the air/water interface. Biochim Biophys Acta 1560: 1-13.

ROSSINI CVT, MOLINA C AND CASELI L. 2017. Langmuir and Langmuir-Blodgett films of di-ureasil 
hybrid compounds containing phosphotungstic acid. Coll Surf A 524: 35-42.

SCHMIDT TF, CASELI L, VIITALA T AND OLIVEIRA JR ON. 2008. Enhanced activity of horseradish peroxidase in Langmuir-Blodgett films of phospholipids. Biochim Biophys Acta 1778: 2291-2297.

SCHOLL FA AND CASELI L. 2015. Langmuir and Langmuir-Blodgett films of lipids and penicillinase: Studies on adsorption and enzymatic activity. Coll Surf B 126: 232-236.

SHARMA SK, SINGHAL R, MALHOTRA BD, SEHGAL N AND KUMAR A. 2004. Lactose biosensor based on Langmuir-Blodgett films of poly(3-hexyl thiophene). Biosens Bioelectron 20: 651-657.

SIQUEIRA JR JR, CASELI L, CRESPILHO FN, ZUCOLOTTO V AND OLIVEIRA JR ON. 2010. Immobilization of biomolecules on nanostructured films for biosensing. Biosens Bioelectron 25: 1254-1263.

SRIYUDTHSAK M, YAMAGISHI H AND MORIIZUMI T. 1988. Enzyme-immobilized Langmuir-Blodgett film for a biosensor. Thin Solid Films 160: 463-469.

SUN Q, ZORIN NA, CHEN D, CHEN M, LIEU TX, MYAKE J AND QIAN DJ. 2010. Langmuir-Blodgett Films of Pyridyldithio-Modified Multiwalled Carbon Nanotubes as a Support to Immobilize Hydrogenase. Langmuir 26: 10259-10265.

SWALEN JD ET AL. 1987. Molecular monolayers and films. A panel report for the Materials Sciences Division of the Department of Energy. Langmuir 3: 932-950.

TAKATSU I AND MORIIZUMI T. 1987. Solid-State Biosensors Using Thin-Film Electrodes. Sens Actuators 11: 309-317.

TANG FQ, LI JR, ZHANG L AND JIANG L. 1992, Improvement of enzymatic-activity and lifetime of langmuir-blodgett-films by using submicron sio2 particles. Biosens Bioelectron 7: 503-507.

TATSUMA T, TSUZUKI H, OKAWA Y, YOSHIDA S AND WATANABE T. 1991. Bifunctional Langmuir-Blodgett film for enzyme immobilization and amperometric biosensor sensitization. Thin Solid Films 202: 145-150.

WAN K, CHOVELON JM AND JAFFREZIC-RENAULT N. 2000. Enzyme-octadecylamine Langmuir-Blodgett membranes for ENFET biosensors. Talanta 52: 663-670.

WANG S, YIN F AND TU Y. 2010. A Uric Acid Biosensor Based on Langmuir-Blodgett Film as an EnzymeImmobilizing Matrix. Analyt Lett 4: 1507-1515.

WANG XY, YIN F AND TU YF. 2010. A uric acid biosensor based on langmuir-blodgett film as an enzymeimmobilizing matrix. Anal Lett 43: 1507-1515.

YANO YF, URUGA T, TANIDA H, TERADA Y AND YAMADA H. 2011. Protein Salting Out Observed at an Air-Water Interface. J Phys Chem Lett 2: 995-999.

ZAITSEV SY. 1993. Functional Langmuir films with glucose oxidase. Coll Surf A 75: 211-216.

ZANON NCM, OLIVEIRA JR ON AND CASELI L. 2012. Immbolization of uricase enzyme in Langmuir and Langmuir-Blodgett films of fatty acids: Possible use as a uric acid sensor. J Colloid Interf Sci 373: 69-74.

ZHENG J, CONSTANTINE CA, RASTOGI VK, CHENG T, DEFRANK JJ AND LEBLANC RM. 2004. Secondary Structure of Organophosphorus Hydrolase in Solution and in Langmuir-Blodgett Film Studied by Circular Dichroism Spectroscopy. J Phys Chem B 108: 17238-17242.

ZHU DG, PETTY MC, ANCELIN H AND YARWOOD J. 1989. On the formation of langmuir-blodgett films containing enzymes. Thin Solid Films 176: 151-156. 